\title{
MAJOR CENTRAL NERVOUS SYSTEM MALFORMATIONS IN SOUTH WALES \\ II. PREGNANCY FACTORS, SEASONAL VARIATION, AND SOCIAL CLASS EFFECTS
}

BY

K. M. LAURENCE, M.A. (Cantab.), M.B., Ch.B. (L'pool), M.C.Path. Senior Lecturer in Paediatric Pathology, Department of Child Health, Welsh National School of Medicine, Llandough Hospital, Penarth, Glamorgan, and Hon. Consultant Pathologist, United Cardiff Hospitals

AND

C. O. CARTER, M.A. (Oxon.), D.M. (Oxon.), F.R.C.P.

Director, Medical Research Council's Clinical Genetics Research Unit, Institute of Child Health, London, W.C.I.

AND

P. A. DAVID, Dip. Soc. Sci.

Research Social Worker, Department of Child Health, Welsh National School of Medicine

This is a report on part of a survey which began in 1960 in the Vale of Glamorgan and the mining valleys of Monmouthshire and Glamorgan east of the Neath Valley to investigate genetic and the environmental factors affecting the incidence of the major central nervous system (neural tube) malformations. Details of the survey area, total birth population, ascertainment methods, incidence, and the possible relation of geographical factors to the wide local variations observed have already been published (Laurence, Carter, and David, 1968). The genetic aspects of the survey (Carter, Laurence, and David, 1968) and the natural history of spina bifida (Laurence, Tew, David, and Carter, 1968) are the subject of other publications. We here present and assess the significance of some of the pregnancy, seasonal, and social factors.

The population of the survey area, which excluded the Urban areas of Newport, Cardiff, Penarth, Barry, and Neath, was about 850,000. Between 1956 and 1962 (inclusive) there were 102,786 total births in that area, and among them there were 364 cases of anencephaly, 425 of spina bifida cystica and encephalocoele (henceforth referred to as spina bifida), and 46 cases of hydrocephalus, giving a total of 835 cases of neural tube malformation, an overall incidence of $8 \cdot 12$ per 1,000 births. The incidence of spina bifida $(4 \cdot 13)$ is the highest reported for any series for a whole population, and that for anencephaly $(3 \cdot 54)$ is exceeded only in the Northern Ireland series of Stevenson and Warnock (1959). All instances of acquired hydrocephalus were excluded and cases of hydrocephalus secondary to spina bifida were classed as spina bifida. This accounts for the unusually low incidence of 0.45 for congenital hydrocephalus.

\section{MethodS}

Tracing Index Cases

An attempt was made to trace and then to visit all the families of the 835 cases uncovered by the survey. Many had moved house, as sometimes eight years had elapsed between the birth of the index case and the interview. The Local Health Authority was often able to supply a new address through the health visitor. Otherwise, methods suggested by Laurence (1959) were followed.

The local Executive Council was able to supply the name of the new general practitioner when families had moved within the same district, or of the new Executive Council when they had moved to another district. Sometimes the Central National Health Service Registry in Southport was asked to forward letters. For this it was necessary to discover the National Health Service number from the Executive Council, local Registry of Births and Deaths, or occasionally hospital records. In one case the Police, in another the Ministry of Social Security, and in another the Service authorities, were able to put us into contact with the family. In two instances, the former general practitioner made inquiries about the new addresses from relatives still living in the area. Ten difficult cases were referred to the International Department of the Salvation Army, which put us in touch with seven families. Only five cases eluded us, and 830 were traced.

Selection of Index Cases and Controls for INTERVIEWING

With 835 index cases there was neither the time nor the resources for all cases to be visited by ourselves. We therefore chose for detailed study and personal visiting first, all the cases ascertained for 
the whole 7 years in the four Glamorgan divisions of Rhondda, Aberdare, Caerphilly, and Merthyr, and second, the cases born in the 3-year period, $1960-62$, in the other eight divisions. These we have called the "interview cases", and there were 551 of them (Table I). The remaining 284 index cases not selected for visiting were called "questionnaire cases" (see below).

TABLE I

INDEX CASES AND CONTROLS

\begin{tabular}{l|c|c|c}
\hline \multirow{2}{*}{ Division } & \multirow{2}{*}{ Controls } & \multicolumn{2}{c}{ Index Cases } \\
\cline { 2 - 4 } & $\begin{array}{c}\text { Interview } \\
\text { Cases }\end{array}$ & $\begin{array}{c}\text { Questionnaire } \\
\text { Cases }\end{array}$ \\
\hline Neath & 7 & 14 & 13 \\
\hline Port Talbot & 13 & 26 & 29 \\
\hline Mid-Glamorgan & 21 & 42 & 69 \\
\hline Glamorgan South-east & 8 & 16 & 12 \\
\hline Pontypridd & 18 & 35 & 25 \\
\hline Rhondda & 44 & 86 & - \\
\hline Aberdare & 28 & 56 & - \\
\hline Caerphilly & 44 & 93 & - \\
\hline Merthyr & 27 & 51 & - \\
\hline Rhymney & 20 & 39 & 64 \\
\hline Ebbw Vale & 28 & 55 & 52 \\
\hline East Monmouthshire & 19 & 38 & 20 \\
\hline Total & 277 & 551 & 284 \\
\hline
\end{tabular}

By the random numbers technique, half of the interview cases in each district were chosen to have controls matched for sex, place of residence, and date of birth. The 277 control cases were selected from the nearest entries in the Local Birth Registers; only two proved unsuitable, one an infant with spina bifida, then transferred to the index group, and the other an illegitimate child for whom there was no possibility of investigation. For these two other controls were chosen.

We sent a letter to all the parents in which we arranged an interview, explained the purpose of the investigation, and asked them to be prepared to talk about their relatives.

The interview was semi-structured, and a schedule was completed from notes immediately afterwards. The interviews were all carried out by P. A. David, though several families of interest were also visited by one or both of the other authors. In addition to age, occupation of parents, and their home circumstances, information was sought about the infant, the pregnancy (illnesses, vaccinations, $x$ rays, drugs, full-time employment during the first tri- mester, etc.), the delivery, and the post-natal and later period. We also asked what explanation had been given to the family by medical and ancillary and personal services and what was the mother's attitude to having further children. A full obstetric history and a family tree of second and third degree relatives was obtained, and information about the birthplace and occupation of grandparents and where possible great-grandparents was collected. The interview generally lasted about one hour.

We were successful in visiting 93.8 per cent. of the "interview" sample of index cases (all but 34) and $95 \cdot 3$ per cent. of the control cases (all but 13). In nearly all the 47 cases left uninterviewed by us, most of the information needed was obtained through the general practitioner, the Local Health Authority medical officer, or health visitor, and in three instances through a close relative. Amongst these were fifteen absolute refusals, and seven "hidden" refusals (the parents chose to be out on repeated visiting).

There were eight other families left unvisited for fear of disturbing a new or difficult social situation. In two, the mother had recently died of a malignant disease, in four the infant was illegitimate, one was about to emigrate, and the remaining family was itinerant. There were nine families who had moved out of the district and two cases who were inadvertently classed as questionnaire cases until after the interviewing was completed.

Three of the five untraceable cases, an Indian doctor who had returned home, an itinerant gipsy family, and an unmarried girl, were interview cases. Scant data from hospital records had to suffice for these.

The mother was seen in all but seven of the index families interviewed, in 157 together with the father, and in another eight with some other member of the family. Often the mother's mother or sister, less often her father or other relative, was also present to help with the family details. In three cases in which the mother was not questioned, the father only or some member of his family was seen; in the remaining four, one of the close relatives of the mother was interviewed.

\section{Questionnaire Cases}

In eight divisions, Neath, Port Talbot, MidGlamorgan, Glamorgan South-east, Pontypridd, Rhymney, Ebbw Vale, and East Monmouthshire, the 284 cases born between 1956 and 1959 were visited on our behalf by the Local Authority's health visitors, or when families had moved out of the area, by the local general practitioner. These were the questionnaire cases. A questionnaire and 
an explanatory sheet setting out our aims and requirements was presented. These included the date of birth of parents, occupation of father, information about any consanguinity, and the full obstetric history, including stillbirths or miscarriages, with dates and causes and details of any malformations. The duration of pregnancy was inquired into at a later date.

Five questionnaires were returned not completed, including three where there was illegitimacy and two where the family had moved away. There were also two questionnaire cases who were untraced: a widow, who may well have changed her name through remarriage, and a woman who emigrated to Australia. For these, incomplete information from hospital, local health authority records, or relatives had to suffice.

\section{Results}

The sections on information given to the mother, events in pregnancy, and social class were based on the 551 interview cases only; for length of gestation, sex ratios, and seasonal variations all the 835 Index cases were used.

\section{INFORMATION GIVEN TO THE MOTHER}

How much the mother knows about the malformation of her child will profoundly affect the interviewing technique. In only half the spina bifida infants, usually those who had survived some time, and one-fifth of the anencephalic and hydrocephalic infants, did the mother have any clear idea about the malformation. In these cases the explanation had usually been given by a hospital doctor or general practitioner. Mothers confined at home sometimes saw the malformed infant and realized what was the matter before anybody had an opportunity to explain. On the other hand, at the time of this interview 14 per cent. of mothers of anencephalics, 16 per cent. of mothers of hydrocephalics, and 3 per cent. of mothers of spina bifida infants did not even suspect that there had been anything at all abnormal. In these cases the infants were generally stillborn or had died shortly after birth. Many of the remaining mothers had been given only very incomplete and unsatisfactory explanations. For instance, 32 per cent. of those who had anencephalics, 13 per cent. of those with spina bifida infants, and 19 per cent. of those who had given birth to hydrocephalics had apparently been told without further details that their infant was "deformed". In addition, 11 per cent. of the mothers of anencephalics, 12 per cent. of those of hydrocephalics, and 2 per cent. of those of spina bifida infants had been given the general impression that $\frac{3}{\Phi}$ their child was merely premature, having been told $\stackrel{0}{?}$ that it was "not properly developed". Others had $\Rightarrow$ been told more specifically that the head or back $\stackrel{?}{+}$ had not been properly formed $(9$ per cent. anen- $?$ cephalus, 6 per cent. spina bifida, and 23 per cent. $\frac{\bar{D}}{\bar{D}}$ hydrocephalus); in the case of spina bifida infants, 11 per cent. of the mothers were told that the child $\stackrel{ه}{\circ}$ would not live long, but nothing more. Some mothers \& suspected that their husbands had been taken into $\vec{\circ}$ medical confidence, although they themselves had not been informed.

Thus some mothers seemed unaware of their infant's malformation ( 27 per cent. of anencephalus, 25 per cent. of hydrocephalus, and 15 per cent. of spina bifida) and many of the remainder had a very $N$ incomplete idea of what was the matter. It has to be borne in mind that some may have been told $\vec{N}$ but had not comprehended (Hare, Laurence, Payne, 을 and Rawnsley, 1966). However, at that time in South Wales and also in Dublin (Coffey and Jessop, 1957) it was common for midwives at home deliveries, and also for some hospital staff, to conceal a serious malformation from the mother, With growing public awareness of this group of $\vec{\oplus}$ conditions, this is no longer the common practice in South Wales. Extreme care and tact has to be exercised in interviewing when there is variation in mother's awareness of what had occurred. A number of mothers, in fact, asked the interviewer what had been wrong with their children, and seemed grateful for the information given; in some instances, it was clear that the giving of such information might have led to recriminations, accusations, and unnecessary distress.

\section{Pregnancy Factors}

Specific questions were asked about the planning of the pregnancy. Altogether only 54 per cent. of the pregnancies of index cases and almost the same percentage (55 per cent.) of controls were, in fact, said to have been planned. Fewer of the index first pregnancies seem to have been planned than the controls (60 and 72 per cent. respectively), but rather more of the fourth and subsequent pregnancies (17 and 7 per cent. respectively). Evidence of serious but unsuccessful attempts at interrupting unwanted pregnancies was obtained in only three index cases and in two controls.

The illegitimacy rate among index cases was $2 \cdot 3$ per cent., not significantly different from that amongst the control group, $(1 \cdot 8$ per cent.). In the area as a whole the percentage of illegitimate births has varied from year to year between 2.5 and $3 \cdot 1$ per cent. 
The proportion of mothers who worked outside the home during the first trimester was again much the same in the index group ( 33.6 per cent.) as in the control group ( 32.9 per cent.).

Events of Pregnancy.-The hazards of retrospective inquiry into the events of pregnancy are well known. The mother of an affected child naturally makes a more determined effort to remember any events, than does the control mother.

(a) Acute Pyrexial Illnesses.-The interviewed mothers were asked specifically about any acute pyrexial episodes during the first and the second month of pregnancy. The only difference of note between index cases and controls was in relation to influenza. Thirty index cases of influenza and of acute bronchitis (which may have had an influenzal aetiology) contrasting with only four amongst the controls is of interest, in view of several reports suggesting that influenza may be an aetiological factor in neural tube malformations (Coffey and Jessop, 1959, 1963; Saxén, Hjelt, Sjöstedt, Hakosalo, and Hakosalo, 1960; Babbott and Ingalls, 1962).

(b) Chronic Illness in Parents.-36 parents (25 mothers and 11 fathers) of index cases and eighteen of controls (10 mothers and 8 fathers) were reported to be suffering from chronic illness, the percentage being identical in the two groups. It seemed that parents were under-reporting their chronic illnesses.

(c) $X$ rays during the First 2 Months.-Only four mothers of index cases and two of control remembered having $x$ rays to the body, mostly chest $x$ rays for various reasons.

(d) Drugs.-Information about drugs obtained by interviewing the parents only was bound to be incomplete and misleading, especially when the drug was often not identified. One hundred index cases and thirty controls had taken medicaments during the first 2 months. Amongst these the nine index cases who had taken amphetamine and two who were on cortisone (none of either in the controls) may be of interest.

LENGTH OF GeStATION.-The duration of pregnancy varied considerably for the three main malformations. The cases of spina bifida included only a slightly greater proportion of premature births than the control group (Fig. 1 and Table II), a rather higher percentage of the hydrocephalics were premature, and the anencephalics tended to

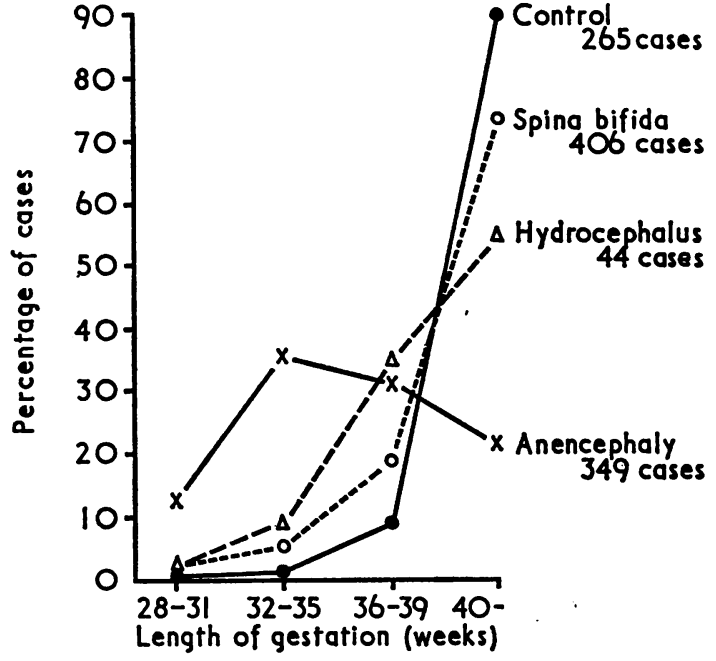

Fig. 1.-Graph showing length of gestation of index and control cases. Length of gestation in 36 index and 12 control cases was not known.

TABLE II

LENGTH OF GESTATION

\begin{tabular}{c|c|c|c|c|c|c|c}
\hline \multirow{2}{*}{ Diagnosis } & \multirow{2}{*}{ Sex } & \multicolumn{5}{|c|}{ Maturity (wks) } & \multirow{2}{*}{ Total } \\
\cline { 2 - 8 } & & $28-31$ & $32-35$ & $36-39$ & $40+$ & $\begin{array}{c}\text { Not } \\
\text { known }\end{array}$ & \\
\hline \multirow{2}{*}{ Anencephaly* } & M & 11 & 29 & 21 & 25 & 5 & 91 \\
\cline { 2 - 8 } & F & 31 & 94 & 87 & 51 & 8 & 271 \\
\hline \multirow{2}{*}{ Hydrocephalus } & M & 4 & 10 & 35 & 142 & 9 & 200 \\
\hline & F & 4 & 13 & 41 & 157 & 10 & 225 \\
\hline \multirow{2}{*}{ Controls } & F & - & 4 & 7 & 17 & 1 & 29 \\
\hline
\end{tabular}

* In two cases of anencephaly the sex is not known.

be severely premature. There is no doubt that the anencephalic pregnancy as opposed to that resulting in a spina bifida infant is often obstetrically abnormal. This is supported by the fact that in South Wales 82 per cent. of the anencephalics were born in hospital (compared with 64 per cent. of the spina bifidas and 65 per cent. of the Controls). It is well known that anencephalics tend to have an unstable lie and to be associated with hydramnios, which may result in premature labour, but in how many mothers labour was actually induced is not known with sufficient accuracy to warrant analysis. The proportion of severely premature, term, and near term deliveries in the South Wales anencephalics was almost the same as that recorded in Liverpool 
(Smithells, Chinn, and Franklin, 1964) and in Rhode Island (MacMahon, Pugh, and Ingalls, 1953) but differed a little from the figures published for Birmingham (McKeown and Lowe, 1951) where there were more full-term anencephalic births.

\section{Sex Ratios}

A very large preponderance of females amongst anencephalic births has always been reported and this series, with only $25 \cdot 1$ per cent. males, is no exception. Only in the small series of Coffey and Jessop (1955), with $14 \cdot 1$ per cent. of males, was there such an excess of females (Table III). In contrast, the number of males and females with spina bifida is generally much more even, although still with a slight excess of females. In South Wales the proportion of males, $47 \cdot 1$ per cent., was higher than in most other series. The 37.0 per cent. of male hydrocephalics in the small South Wales series differs from the percentage in most other series, where with the exception of Birmingham there was either some excess of males or the numbers were equal.

Although numbers were too small to be confident, it would appear that male births had a longer gestation than females for both spina bifida and anencephaly. This had also been observed in Birmingham (McKeown and Lowe, 1951) and in Rhode Island (MacMahon and others, 1953), but not in Liverpool (Smithells and others, 1964; Smithells and Chinn, 1965). In both malformations there was a higher proportion of males amongst the live births (Table IV).

The significance of the difference between the groups in respect of sex ratios and of gestational length is not clear. Some anencephalics are probably lost as early abortions (Nishimura, Takano, Tanimura, Yasuda, and Uchida, 1966), but the suggestion that excessive losses of males account for the great
TABLE IV

SEX RATIO IN SOUTH WALES

(percentage of males)

\begin{tabular}{l|r|c|r|r|r|r}
\hline \multirow{2}{*}{ Malformation } & \multicolumn{2}{|c|}{ Total } & \multicolumn{2}{c|}{ Liveborn } & \multicolumn{2}{c}{ Stillborn } \\
\cline { 2 - 7 } \cline { 3 - 7 } & No. & $\begin{array}{c}\text { Per cent. } \\
\text { Males }\end{array}$ & No. & $\begin{array}{c}\text { Per cent. } \\
\text { Males }\end{array}$ & No. & $\begin{array}{c}\text { Per cent. } \\
\text { Males }\end{array}$ \\
\hline Anencephalus* & 362 & $25 \cdot 1$ & 11 & $45 \cdot 5$ & 351 & $24 \cdot 5$ \\
\hline Spina Bifida & 425 & $47 \cdot 1$ & 315 & $48 \cdot 3$ & 110 & $43 \cdot 6$ \\
\hline Hydrocephalus & 46 & $37 \cdot 0$ & 9 & $22 \cdot 2$ & 37 & $40 \cdot 5$ \\
\hline
\end{tabular}

* In two the sex was not known.

preponderance of females that reach the 28th week of gestation is not borne out by what little evidence $N$ is available. Indeed the evidence suggests that female anencephalics are less viable and tend to have $\vec{N}$ the shorter gestations. With spina bifida, females not only predominate amongst those stillborn, but also seem to have a somewhat greater post-natal mortality, suggesting either that the condition in them tends to be more severe or that they succumb more easily to the complications than the males (Laurence, 1966).

\section{Seasonal Variation}

To examine seasonal variation, the distribution of total births by month of birth in the investigated area from 1956-62 had to be estimated by extrapolation as this information was available only for the Glamorgan divisions. The estimated total varied somewhat from just below $\mathbf{8 , 0 0 0}$ in February and November to over 9,400 in March.

There was no immediately apparent relation between the month of birth of the community's children and that of the central nervous system malformed cases taken together or of the two main groups taken separately (Table V, opposite).

TABLE III

SEX RATIOS IN VARIOUS INVESTIGATIONS (percentage of males)

\begin{tabular}{l|l|l|l|c|c}
\hline \multicolumn{1}{c|}{ Area } & \multicolumn{1}{c|}{ Author } & Date & Anencephalus & Spina Bifida & Hydrocephalus \\
\hline South Wales & Present Study & 1968 & $25 \cdot 1$ & $47 \cdot 1$ & $37 \cdot 0$ \\
\hline Scotland & Record and McKeown & 1949 & $26 \cdot 7$ & $43 \cdot 2$ & $50 \cdot 9$ \\
\hline Birmingham & Record and McKeown & 1949 & $32 \cdot 0$ & $43 \cdot 0$ & $43 \cdot 3$ \\
\hline Liverpool & Smithells & 1964,1965 & $29 \cdot 4$ & $45 \cdot 7$ & - \\
\hline Dublin & Coffey and Jessop & 1955 & $14 \cdot 1$ & $41 \cdot 2$ & $52 \cdot 3$ \\
\hline New York & Gittelsohn and Milham & 1962 & $32 \cdot 9$ & $43 \cdot 2$ & $54 \cdot 6$ \\
\hline Rhode Island & MacMahon and others & 1953 & $30 \cdot 5$ & $46 \cdot 1$ & $55 \cdot 0$ \\
\hline
\end{tabular}


TABLE V

MONTHLY VARIATION IN INCIDENCE

\begin{tabular}{|c|c|c|c|c|c|c|c|c|c|}
\hline \multirow{2}{*}{ Month } & \multirow{2}{*}{$\begin{array}{l}\text { Estimated } \\
\text { Total Births }\end{array}$} & \multicolumn{2}{|c|}{ Anencephaly } & \multicolumn{2}{|c|}{ Spina Bifida } & \multicolumn{2}{|c|}{ Hydrocephalus } & \multicolumn{2}{|c|}{$\begin{array}{c}\text { Total } \\
\text { Central Nervous } \\
\text { System Malformations }\end{array}$} \\
\hline & & Conceived & Born & Conceived & Born & Conceived & Born & Conceived & Born \\
\hline January & 8,696 & 31 & 31 & 41 & 31 & 1 & 9 & 73 & 71 \\
\hline February & 7,988 & 28 & 14 & 31 & 31 & 3 & 2 & 62 & 47 \\
\hline March & 9,433 & 37 & 42 & 33 & 43 & 6 & 4 & 76 & 89 \\
\hline April & 8,885 & 26 & 34 & 25 & 29 & 6 & 4 & 57 & 67 \\
\hline May & 9,096 & 19 & 30 & 24 & 34 & 4 & 3 & 47 & 67 \\
\hline June & 8,483 & 29 & 23 & 36 & 41 & 5 & 2 & 70 & 66 \\
\hline July & 8,629 & 39 & 32 & 28 & 43 & 3 & 2 & 70 & 77 \\
\hline August & 8,445 & 28 & 34 & 32 & 32 & 3 & 3 & 63 & 69 \\
\hline September & 8,706 & 25 & 31 & 44 & 43 & 3 & 7 & 72 & 81 \\
\hline October & 8,279 & 26 & 31 & 40 & 37 & 2 & 4 & 68 & 72 \\
\hline November & 7,932 & 33 & 32 & 34 & 36 & 4 & 3 & 71 & 71 \\
\hline December & 8,214 & 30 & 30 & 36 & 25 & 4 & 3 & 70 & 58 \\
\hline Total & 102,786 & 351 & 364 & 404 & 425 & 44 & 46 & 799 & 835 \\
\hline Not known & - & 13 & - & 21 & - & 2 & - & 36 & - \\
\hline
\end{tabular}

In view of the specially high proportion of premature births amongst the anencephalics, month of conception is probably a better index of seasonal effects than month of birth. Accordingly, the month of conception of the malformed cases was compared with the estimated month of conception of the births in the community. That of the index cases was estimated from the date of the last menstrual period by adding 14 days in the 799 cases where

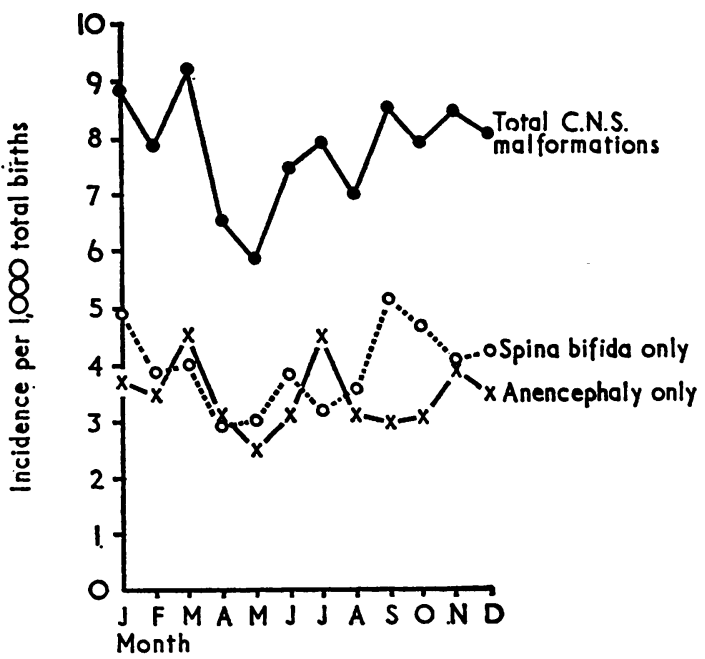

FIG. 2.-Malformation rates corrected for month of conception. In 36 cases the month of conception was not known. the former was known, and that of the community, by subtracting 9 months from the birth month. The monthly malformation rate (Fig. 2) now showed a trend, with rather more conceptions from September to March. Further, the curves for anencephaly and spina bifida showed a similarity which was not apparent when taking birth dates. Although the quarterly rates (Fig. 3), based on date of conception (after some allowance has been made for those

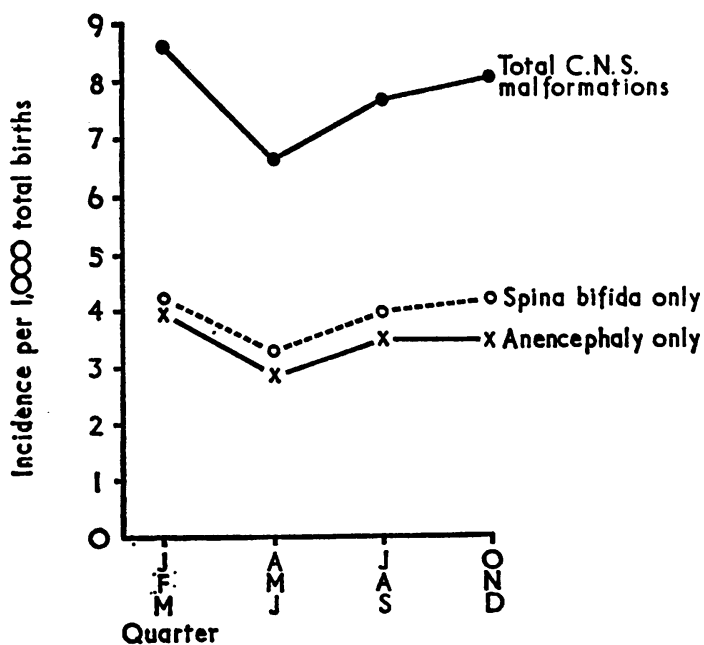

Fig. 3.-Malformation rates by quarter of conception. In 36 cases the length of gestation was not known. (The letters denote the months.) 
cases where the date is not known), for spina bifida and for anencephaly separately showed no significant periodic effect, a significant seasonal effect was obtained when anencephaly and spina bifida were combined $(P<0.02)$. When the cases of hydrocephalus were added the trend was no longer significant.

No seasonal variation for either anencephalic births or conception dates was found in Liverpool (Smithells and others, 1964) and it was found only for birth dates in Rhode Island, but most other investigators have shown some variation. The usual finding is an excess of winter births, marked in Scotland (Edwards, 1961) and Birmingham (McKeown and Record, 1951; Leck and Record, 1966), but less obvious in Southampton (Williamson, 1965) and in England and Wales (Slater, Watson and McDonald, 1964), suggesting that there is an excess of spring and early summer conceptions which is exactly opposite to that found in South Wales.

Most of the above-mentioned investigations into seasonal variation give negative results for spina bifida. However, Guthkelch (1962) in Manchester, and Slater, Watson, and McDonald (1964) in England and Wales, found an excess of winter spina bifida births, which just reached significant levels. Smithells and Chinn (1965) also had a significant excess of winter births, but this disappeared when conception dates were taken, as a large number of summer conceptions were born prematurely.

A review of the quarterly malformation conception rates in our investigation shows very considerable variations from year to year, with peaks in

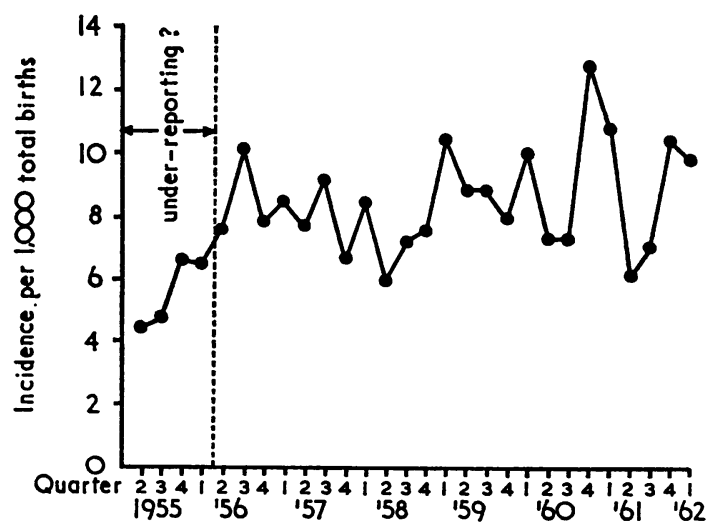

FIG. 4.-Quarterly incidence by date of conception between 1955 and 1962. In the 36 cases in which the conception date was not known, an estimate was made on the basis of 35,38 , and 39 weeks of gestation for cases of anencephaly, hydrocephalus, and spina bifida respectively. For the first year there was probably under-reporting. (The numbers denote the quarter of the year.) different quarters (Fig. 4). At first the length of $\frac{3}{3}$ gestation was available only for all index cases born $\stackrel{8}{\circ}$ between 1960 and 1962. In this period a marked peak was recorded for the last quarter of 1960 and $\stackrel{\vec{S}}{+}$ the first of 1961, when there had been a severe 0 epidemic of influenza " $A$ " in South Wales. Although this peak was not significantly outside the statistically-expected quarterly variation, taken together with the relative increase in cases of influenza in our Index cases and with some recent reports (Coffey and Jessop, 1959, 1963; Saxén and others, 1960; Babbott and Ingalls, 1962) it induced us to ascertain gestation lengths for the cases born before 1960 so as to include the second and third quarters of 1957 when the previous large influenza epidemic occurred. No peak was found to coincide with these quarters, suggesting that influenza " $A$ " was unlikely to have been the aetiological factor in the 1961 "peak".

\section{Social Class Effects}

The effect of social class was examined by comparing the index families with the matched controls. As this is predominantly an industrial and mining area, relatively few professional families were included. Indeed, the control group was comprise almost entirely of families in the Registrar General' Social Class III and IV, and socio-economie groups 9,10 , and 12 , with surprisingly few unskilled workers (Table VI, opposite). The fact that all miners working underground are classed as skilled manual workers is relevant here. Unfortunately, the number of controls was rather small. Ideally this should be controlled by data on the whole community.

The social class effects were examined by grouping them, because of small numbers, into three (Table VII, opposite). A highly significant social class gradient was present for the neural tube malformations as a whole $(\mathrm{P}<0.001)$, with Group 3 families having a higher incidence than Group 1. Taking the two main malformations separately, spina bifida families showed a highly significant gradient $(P<0.001)$, but there seemed to be no social class gradient at all for anencephaly, though there was a slight deficiency of anencephalics in Group 1 families. Almost exactly the same was seen for socio-economic grouping. Using another index of living standard it was found that rather more control families lived in "owner-occupied" houses than index families, while more of the latter lived in privately-rented houses (mostly National Coal Board) or with their parents. These differences do not reach statistical significance.

Concerning the actual industry in which the breadwinner worked, rather more were in mining 
TABLE VI

SOCIAL CLASS

(percentage of cases)

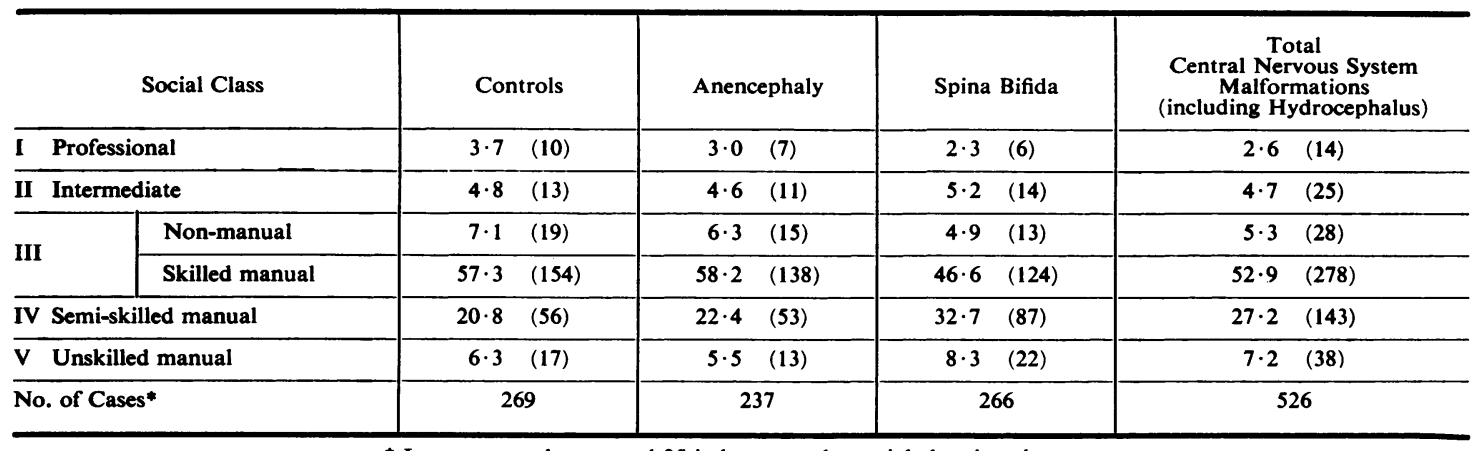

* In two control cases and 25 index cases the social class is unknown.

The number of cases are given in brackets.

TABLE VII

SOCIAL CLASS GROUPING

\begin{tabular}{|c|c|c|c|c|c|c|c|c|c|}
\hline \multirow{2}{*}{\multicolumn{2}{|c|}{ Social Class Groups }} & \multicolumn{2}{|c|}{ Controls } & \multicolumn{2}{|c|}{ Anencephaly } & \multicolumn{2}{|c|}{ Spina Bifida } & \multicolumn{2}{|c|}{$\begin{array}{c}\text { Total } \\
\text { Central Nervous System } \\
\text { Malformations } \\
\text { (including Hydrocephalus) }\end{array}$} \\
\hline & & $\begin{array}{l}\text { No. of } \\
\text { Cases }\end{array}$ & Per cent. & $\begin{array}{l}\text { No. of } \\
\text { Cases }\end{array}$ & Per cent. & $\begin{array}{l}\text { No. of } \\
\text { Cases }\end{array}$ & Per cent. & $\begin{array}{l}\text { No. of } \\
\text { Cases }\end{array}$ & Per cent. \\
\hline 1 & I, II, and Non-manual III & 42 & $15 \cdot 6$ & 33 & $14 \cdot 0$ & 33 & $12 \cdot 4$ & 67 & $12 \cdot 7$ \\
\hline 2 & Manual III & 154 & $57 \cdot 2$ & 138 & $58 \cdot 3$ & 124 & $46 \cdot 6$ & 278 & $52 \cdot 9$ \\
\hline 3 & IV and V & 73 & $27 \cdot 2$ & 66 & $27 \cdot 7$ & 109 & $41 \cdot 0$ & 181 & $34 \cdot 4$ \\
\hline \multicolumn{2}{|c|}{ Total } & 269 & 100 & 237 & 100 & 266 & 100 & 526 & 100 \\
\hline
\end{tabular}

and the steel industry in index than control families. This was again more obvious for spina bifida than anencephaly, but the difference was not significant. On dividing the survey area into a high incidence and a low incidence area (Laurence and others, 1968), no significant differences were found between the two areas in respect of social class, socioeconomic group structure, or housing, for either control or index families.

Marked social class effects have been reported from Scotland (Edwards, 1958), where from 1950-56 the legitimate anencephaly, spina bifida, and hydrocephalic stillbirth rates were respectively four times, twice, and one and a half times as high in Social Class $\mathrm{V}$ as in Class I. In Boston all white ethnic groups, except the Jewish, showed a class gradient for anencephaly and spina bifida which was strongest in Irish Catholic families (Naggan and MacMahon, 1967). Even in Southampton, where numbers were small, a social class effect was noted, with an excess of both anencephaly and spina bifida in Class III and IV families (Williamson, 1965). A considerable social class gradient was also found for England and Wales as a whole for both malformations during the 1958 Perinatal Mortality Survey (Alberman, 1968). On the other hand, in Birmingham (Record and McKeown, 1949), no special class gradient was found when using locality, type of housing, and legitimacy (but not occupation of the father) as the index. In Dublin, Coffey and Jessop (1957) found an excess of unemployed among the fathers of anencephalics, but a corresponding deficit of casual workers. The absence of a social class gradient for anencephaly in South Wales in the presence of a marked effect for spina bifida is difficult to explain. It may, however, be that a gradient for anencephaly is masked because of the small number of Class I and II families, or because the families in those classes may be sharing many of the living standards of Class III.

\section{Discussion}

It is now a commonplace that the aetiology of neural tube malformations (anencephalus and spina bifida) like that of other common malformations involves both genetic predisposition and environmental 
triggers. The indications for genetic predisposition are the familial concentrations of the disorders and their varied incidence in different races. The increased risk to sibs of Index cases has been demonstrated in a number of surveys including the present one (Carter and others, 1968). An increased risk to other degrees of relatives has not been so clearly demonstrated, owing to the technical difficulties in collecting reliable family histories. Such familial concentration is prima facie evidence for a polygenically inherited predisposition, though common family environment cannot be excluded. The striking racial variations in the incidence of neural tube malformations are well documented (Penrose, 1957; Stevenson, Johnston, Stewart, and Golding, 1966). The areas known to have markedly high incidences are the north and west of the British Isles, Amritsar in the Punjab, and Alexandria in Egypt, while the areas with low incidence include all the Far Eastern countries and Africa south of the Sahara. Such regional variations again might be due to environmental factors, rather than to genetic differences. On the whole, however, populations migrating from high or low incidence areas appear to retain their characteristic malformation rate, for example, Sikhs contrasted with Chinese in Singapore (Searle, 1959), Negroes in America (Alter, 1962; Gittlesohn and Milham, 1962), and Jews and Irish in Boston (Naggan and MacMahon, 1967). This suggests that much of the differences in relation to race may be genetically determined. The best general evidence for the importance of environmental factors in aetiology of these malformations are the many reported instances in which only one of a pair of identical twins was affected by a neural tube malformation (references given in Carter, 1965). Little is yet known of the possible environmental triggers in man, but experimental work in rodents shows that a great variety of teratogenic agents may cause neural tube malformations, including $x$ rays, vitamin $\mathbf{E}$ and folic acid deficiency, vitamin $\mathbf{A}$ excess, and a great variety of chemicals agents (Giroud, 1960). In man too it may well be that a variety of environmental agents can cause the malformations in those already genetically predisposed, because no one environmental factor by itself makes a major contribution and so it may not be readily detectable.

The hypothesis that viruses are aetiological agents is attractive in that it might explain the seasonal and social class effects (through virus epidemics, over-crowding, and poor living conditions respectively). The evidence that a virus infection may contribute applies mostly to influenza. Retrospective studies tend to give misleading results (Logan, 1951) and prospective studies usually include too few instances of influenza early in pregnancy to provide $\frac{8}{\varnothing}$ useful information. However, in a prospective study from Dublin, Coffey and Jessop (1959) found $a \stackrel{\vec{F}}{\Rightarrow}$ three-fold increase of neural tube malformations in $\stackrel{S}{\rightarrow}$ mothers who experienced influenza early in pregnancy. Doll, Hill, and Sakula (1960), examining the $\frac{\overline{\bar{g}}}{\bar{m}}$ Scottish stillbirth data carefully, found a possible $\frac{\bar{c}}{\bar{\phi}}$ small increase after the 1957 influenza outbreak, $\stackrel{\square}{\varrho}$ but concluded that the extent of the hazard was small. Leck (1963) found no increase of neural tube $\overrightarrow{0}$ malformations in Birmingham after the epidemics with peaks in October, 1957, February, 1959, and $\vec{\omega}$ January, 1961. In our own series, where accurate conception dates were available, the apparent rise after an epidemic in the winter of 1960 was not $\stackrel{\sim}{\sim}$ paralleled by any similar increase after the $1957 \mathrm{~N}$ outbreak when the incidence remained about average. This is probably evidence against a viral $\frac{N}{N}$ aetiology, even though the low incidence in our series, in conceptions from April to June, would perhaps be more compatible with an effect of viral infections than the finding of Leck and Record of low incidence for conceptions referrable to October and November. In our series the finding of an excessive number of influenza-like illnesses in earlo $\vec{\oplus}$ pregnancy highlights the caution with which suc data from retrospective surveys must be interpreted However, viral aetiology cannot be dismissed without taking into account subclinical infections for which serial serological investigations would be needed (Klemetti, 1967).

Direct interference does not seem to be an aetiological factor (Whitehouse and McKeown, 1956) and in any case attempts at abortion are usually made at a stage when the neural tube malformations are already determined. The only drug shown to have caused this group of malformations in man is aminopterin used as an abortifacient (Thiersch, 1952, 1960).

It has been suggested that nutritional factors might possibly account for seasonal variations, social class effects, and some secular trends. The availability of certain foods with the seasons could account for the first, the poorer nutrition of the lower social groups suggested by Coffey and Jessop (1957) might account for the social class gradient found in most investigations, and the declining incidence reported for example from New York (Gittlesohn and Milham, 1962) might perhaps be related to improving nutritional standards. In Birmingham and Scotland (Leck, 1966) and in the present study there seems to have been either a variable secular trend or no real change.

Nutritional factors could act either through a marked deficiency having a teratogenic effect on 
the developing foetus, or by a relative deficiency removing an inhibition upon the inherited genetic tendency to produce offspring with the malformation (British Medical Journal, 1962). The latter is an attractive notion as severe nutritional deficiencies are now relatively uncommon in Western Europe. Also it is experimental experience that sometimes borderline rather than severe deficiency states produce the malformations. There is some evidence, apart from the experimental and the clinical effect of taking aminopterin, that folic acid deficiency may be playing a part. Green vegetables, one of the sources of folic acid, are less plentiful at the time when estimated conception rates for neural tube malformations in the Scottish data tend to be higher, and so this substance may, in part, be responsible for the seasonal variation. Changes in seasonal variation seen lately in Scotland (Leck and Record, 1966) may reflect changes in habits, such as the use of deep-frozen foods. The report by Hibbard and Smithells (1965) that there is a higher incidence of folic acid metabolism derangement in mothers with anencephalics and spina bifida babies than in those with normal children is of special interest.

\section{SUMmaRY}

This is an investigation into all the 835 cases of central nervous system malformation (anencephaly 364 cases, spina bifida cystica and encephalocoele 425 cases, and congenital hydrocephalus 46 cases) born between 1956 and 1962 in the mining valleys of Glamorgan and Monmouthshire and the Vale of Glamorgan in a total population of 850,000 with 102,786 births. Methods of tracing and following up the cases and of interviewing the index families and their matched controls are given. It was found that many of the mothers had only scant knowledge of their infant's abnormality, which profoundly influenced interviewing techniques.

The only pregnancy factor which could perhaps have an aetiological significance was an increased incidence of influenza. Gestational length of the anencephalic and spina bifida pregnancies was similar to that usually reported, as were the sex ratios. A significantly lower malformation conception rate was found for anencephaly and spina bifida combined for April, May, and June. Quarterly malformation rates using conception dates from 1956-62 failed to show any consistent relationship with epidemics of Influenza " $A$ ". A marked and significant social class effect was found for spina bifida but not for anencephaly.

It was concluded that there is a polygenically inherited predisposition to produce offspring with central nervous system malformations in certain populations, interacting with environmental trigger mechanisms. A virus (influenza "A") aetiology was considered, but nutritional factors such as folic acid deficiency were thought to be more likely.

This investigation could not have been carried out without the unstinting help of our Hospital colleagues, the Local Health Authorities, and the Local General Practitioners, but we are particularly indebted to $\mathrm{Dr}$ W. E. Thomas, County Medical Officer of Health for Glamorgan, Dr G. Rocyn Jones, County Medical Officer of Health for Monmouthshire, and Dr T. H. Stephens, Medical Officer of Health for Merthyr Borough, to their Divisional Medical Officers, Health Visitors, and Midwives, and to the Medical Records Officers of the various hospitals in the area. We should also like to thank the Local Executive Councils, the Central National Health Service Register of the Ministry of Health, and the International Investigation Department of the Salvation Army for their help in tracing families, and Miss J. V. Dunscombe who helped us throughout and for a period as research assistant. We are grateful to Prof. C. R. Lowe, Prof. A. G. Watkins, and Dr H. Campbell of the Welsh National School of Medicine for their advice, and also to Mr G. Berry of the M. R. C. Pneumoconiosis Research Unit. We are indebted to Mrs K. Evans of the M. R. C. Clinical Genetics Research Unit, London, W.C.1, for interviewing some families in the London area and to Mr T. J. H. Cooke for the preparation of illustrations.

This investigation was supported by generous grants from the Mental Health Research Fund and the Endowment Fund of the United Cardiff Hospitals.

\section{REFERENCES}

Alberman, E. D. (1968). "Congenital Malformations in Perinatal Mortality, Second Report of the British Perinatal Mortality Survey." ed. N. R. Butler and E. D. Alberman. Livingstone, Edinburgh.

Alter, M. (1962). Arch. Neurol. (Chic.), 7, 411 (Anencephalus, hydrocephalus, and spina bifida).

Babbott, J. G., and Ingalls, T. H. (1962). Amer. J. publ. Hlth, 52, 2009 (Field studies of selected congenital malformations occurring in Pennsylvania).

British Medical Journal (1962). Brit. med. J., 2, 1041 (Leading article: Seasonal variations in the incidence of congenital malformations).

Carter, C. O. (1965). "The Inheritance of the Common Congenital Malformations", in "Progress in Medical Genetics", vol. 4, ed. A. G. Steinberg and A. G. Bearn, p. 59. Grune and Stratton, New York.

, Laurence, K. M., and David, P. A. (1968). J. med. Genet., 5, 81 (A family study of the major central nervous system malformations in South Wales).

Coffey, V. P., and Jessop, W. J. E. (1955). Irish J. med. Sci., No. 349, p. 30 (Congenital abnormalities).

(1957). Brit.J. prev. soc. Med., 11, 174 (A study of 137 cases of anencephaly).

(1959). Lancet, 2, 935 (Maternal influenza and congenital deformities. A prospective study).

(1963). Ibid., 1, 748 (Maternal influenza and congenital deformities. A follow-up study). 
Doll, R., Hill, A. B., and Sakula, J. (1960). Brit. J. prev. soc. Med., 14, 167 (Asian influenza in pregnancy and congenital defects).

Edwards, J. H. (1958). Ibid., 12, 115 (Congenital malformations of the central nervous system in Scotland).

- (1961). Ann. hum. Genet., 25, 89 (Seasonal incidence of congenital disease in Birmingham).

Gittlesohn, A. M., and Milham, S. (1962). Brit. J. prev. soc. Med., 16, 153 (Declining incidence of central nervous system anomalies in New York State).

Giroud, A. (1960). "Causes and morphogenesis of anencephaly", in "Ciba Foundation Symposium on Congenital Malformations", ed. G. E. W. Wolstenholme and C. M. O'Connor, p. 199. Churchill, London.

Guthkelch, A. N. (1962). Brit. J. prev. soc. Med., 16, 159 (Studies in spina bifida cystica. III. Seasonal variation in the frequency of spina bifida births).

Hare, E. H., Laurence, K. M., Payne, H., and Rawnsley, K. (1966). Brit. med. J., 2, 757 (Spina bifida cystica and family stress).

Hibbard, E. D., and Smithells, R. W. (1965). Lancet, 1, 1254 (Folic acid metabolism and human embryopathy (preliminary communication)).

Klemetti, A. (1967). Acta neurol. scand., 43, Suppl. 31, p. 31 (Environmental factors and congenital malformations of the central nervous system).

Laurence, K. M. (1959). Lancet, 2, 208 (Tracing patients). (1966). Develop. Med. Child Neurol., 8, Suppl. No.11, p. 10. (Hydrocephalus and spina bifida).

., Carter, C. O., and David, P. A. (1968). Brit. J. prev. soc. Med., 22, 146 (The major central nervous system malformations in South Wales. I. incidence, local variations and geographical factors).

, Tew, B. J., David, P. A., and Carter, C. O. (1968). (The natural history of spina bifida). (in preparation).

Leck, I. (1963). Brit. J. prev. soc. Med., 17, 70 (Incidence of malformations following influenza epidemics).

(1966). Lancet, 2, 791 (Changes in the incidence of neural-tube defects).

and Record, R. G. (1966). Brit. J. prev. soc. Med., 20, 67 (Seasonal incidence of anencephalus).

Logan, W. P. D. (1951). Brit. med. J., 2, 641 (Incidence of congenital malformations and their relation to virus infections during pregnancy).

McKeown, T., and Lowe, C. R. (1951). Hum. Biol., 23, 41 (The sex ratio of stillbirths related to cause and duration of gestation).

and Record, R. G. (1951). Lancet, 1, 192 (Seasonal incidence of congenital malformations of the central nervous system).

MacMahon, B., Pugh, T. F., and Ingalls, T. H. (1953). Brit. J. prev. soc. Med., 7,211 (Anencephalus, spina bifida and hydrocephalus. Incidence related to sex, race, and season of birth, and incidence in siblings).
Naggan, L., and MacMahon, B. (1967). New Engl. J. 3 Med., 277, 1119 (Ethnic differences in the prevalence of $\mathbb{D}$ anencephaly and spina bifida in Boston, Massachusetts).

Nishimura, H., Takano, K., Tanimura, T., Yasuda, M., and Uchida, T. (1966). Biol. Neonat., 10, 93 (High incidence of several malformations in the early human embryos as compared with infants).

Penrose, L. S. (1957). J. ment. Defic. Res., 1,4 (Genetics of anencephaly).

Record, R. G., and McKeown, T. (1949). Brit. J. soc. Med., 3, 183 (Congenital malformations of the central nervous system. I-A survey of 930 cases).

Saxén, K., Hjelt, L., Sjöstedt, J. E., Hakosalo, J., and Hakosalo, H. (1960). Acta path. microbiol. scand., 49, 114 (Asian influenza during pregnancy and congenital malformations).

Searle, A. G. (1959). Ann. hum. Genet., 23, 279 (The incidence of anencephaly in a polytypic population).

Slater, B. C. S., Watson, G. I., and McDonald, J. C. N (1964). Brit. J.prev. soc. Med., 18, 1 (Seasonal variation in congenital abnormalities. Preliminary report of a survey conducted by the Research Committee of the $N$ Council of the College of General Practitioners).

Smithells, R. W., and Chinn, E. R. (1965). Develop. Med. Child Neurol., 7, 258 (Spina bifida in Liverpool).

cephaly in Liverpool).

Stevenson, A. C., Johnston, H. A., Stewart, M. I. P., and Golding, D. R. (1966). Bull. Wld Hlth Org., 34, Supp $\vec{c}$ (Congenital malformations. A report of a study of series of consecutive births in 24 centres).

- and Warnock, H. A. (1959). Ann. hum. Genet., 25 . 382 (Observations on the results of pregnancies in women resident in Belfast. I. Data relating to all pregnancies ending in 1957).

Thiersch, J. B. (1952). Amer. J. Obstet. Gynec., 63, 1298 (Therapeutic abortions with a folic acid antagonist, 4aminopteroylglutamic acid (4-amino P.G.A.) administered by the oral route).

(1960). Discussion of paper by M. M. Nelson in "Ciba Symposium on Congenital Malformations", ed. G. E. W. Wolstenholme and C. M. O'Connor, p. 152. Churchill, London.

Whitehouse, D. B., and McKeown, T. (1956). J. Obstet. Gynaec. Brit. Emp., 63, 224 (A note on the significance of attempted abortion in the aetiology of congenital abnormalities).

Williamson, E. M. (1965). J. med. Genet., 2, 161 (Incidence and family aggregation of major congenital malformations of central nervous system. (A survey of 100 families in Southampton)). 